\title{
FACTORS AFFECTING THE PRODUCTION AND REGENERATION OF PROTOPLASTS FROM Colletotrichum lindemuthianum
}

\author{
Fatores que afetam a produção e regeneração de protoplastos \\ de Colletotrichum lindemuthianum
}

\author{
Francine Hiromi Ishikawa ${ }^{1}$, Quélen de Lima Barcelos ${ }^{2}$, \\ Elaine Aparecida de Souza ${ }^{3}$, Eustáquio Souza Dias ${ }^{4}$
}

\begin{abstract}
The present work reports factors affecting the production and regeneration of protoplasts from Colletotrichum lindemuthianum. The usefulness of protoplast isolation is relevant for many different applications and has been principally used in procedures involving genetic manipulation. Osmotic stabilizers, lytic enzymes, incubation time and mycelial age were evaluated in terms of their effects on protoplast yield. The optimal condition for protoplast production included the incubation of young mycelia $(48 \mathrm{~h})$ in 0.6 mol $1^{-1} \mathrm{NaCl}$ as the osmotic stabilizer, with $30 \mathrm{mg} \mathrm{ml}^{-1}$ Lysing Enzymes from Trichoderma harzianum for $3 \mathrm{~h}$ of incubation. In these conditions protoplasts production was higher than $10^{6}$ protoplatos $\mathrm{ml}^{-1}$ in the digestion mixture, number suitable enough for experiments of transformation in fungi. Sucrose concentrations of $1.2 \mathrm{~mol} \mathrm{l}^{-1}$ and $1 \mathrm{~mol} \mathrm{l}^{-1}$ were the most suitable osmotic stabilizers for the regeneration after $48 \mathrm{~h}$, with rates of $16.35 \%$ and $14.54 \%$, respectively. This study produced an efficient method for protoplast production and reverted them into a typical mycelial morphology using a Colletotrichum lindemuthianum LV115 isolate.
\end{abstract}

Index terms: Protoplast formation, lytic enzyme, anthracnose, osmotic stabilizer, filamentous fungi.

\section{RESUMO}

O presente trabalho apresenta os fatores que afetam a produção e regeneração de protoplastos de Colletotrichum lindemuthianum. $\mathrm{O}$ isolamento de protoplastos é muito relevante para diferentes aplicações, principalmente, em procedimentos que envolvem a manipulação genética. Estabilizadores osmóticos, enzimas líticas, tempo de incubação e idade micelial foram testados com relação ao efeito na liberação de protoplastos. As condições otimizadas para produção de protoplastos foram incubação de micélio jovem $(48 \mathrm{~h})$ em estabilizador osmótico $\mathrm{NaCl} 0.6 \mathrm{~mol} \mathrm{l}^{-1}$, acrescido de $30 \mathrm{mg} \mathrm{ml}^{-1}$ da enzima Lysing Enzymes de Trichoderma harzianum incubado, durante $3 \mathrm{~h}$. Nessas condições, a obtenção de protoplastos foi maior que $10^{6}$ protoplatos ml ${ }^{-1}$ na mistura de digestão, número suficientemente adequado para experimentos de transformação em fungos. Sacarose nas concentrações de $1.2 \mathrm{~mol} \mathrm{l}^{-1} \mathrm{e}$ $1 \mathrm{~mol} \mathrm{l}^{-1}$ foram os estabilizadores mais apropriados para a regeneração, após $48 \mathrm{~h}$, sendo as taxas de regeneração de $16.35 \%$ e $14.54 \%$, respectivamente. Este estudo produziu um método eficiente para produção e reversão de protoplastos à morfologia micelial típica de Colletotrichum lindemuthianum utilizando o isolado LV115.

Termos para indexação: Formação de protoplastos, enzima lítica, antracnose, estabilizador osmótico, fungo filamentoso.

(Received in june 18, 2009 and approved in december 10, 2009)

\section{INTRODUCTION}

Anthracnose is one of the most important diseases of the common bean (Phaseolus vulgaris L.). The causal agent of anthracnose is Colletotrichum lindemuthianum (Souza et al., 2007). There have been several studies with this pathogen involving genetic transformation by protoplasts (Rodriguez \& Yoder, 1987; Redman \& Rodriguez, 1994; Dufresne et al., 1998; Dumas et al., 1999). Protoplast release is an important biological tool for experiments addressing genetic transformation and other molecular approaches such as pulsed-field gel electrophoresis (PFGE) and flow cytometry. Molecular transformation has facilitated the understanding of biological phenomena such as host-pathogen interactions, secondary metabolism, environmental stress responses and developmental biology.

Älthough protoplast formation in $C$. lindemuthianum has been reported before, any existing protocol should be used for each strain under study. Furthermore, most of these studies used Novozym 234, however, this enzymatic complex is no commercially available. Factors such as lytic enzymes, osmotic stabilizers, mycelium age and the type of microorganism can affect the maximum release of protoplasts (Peberdy, 1995).

1Universidade Federal de Lavras - Departamento de Biologia/DBI - Cx. P. 3037-37200-000 - Lavras, MG - francinehi@hotmail.com

2University of Kentucky - Department of Plant Pathology - Lexington - USA

${ }^{3}$ Universidade Federal de Lavras - Departamento de Biologia/DBI - Lavras, MG

${ }^{4}$ Universidade Federal de Lavras - Departamento de Biologia/DBI - Lavras, MG 
Hence, it is important to optimize a protocol for the production and regeneration of protoplasts for each species of fungi. The main objective of this work was thus to study factors affecting the production and regeneration of Colletotrichum lindemuthianum protoplasts using Lysing Enzymes from Trichoderma harzianum for use in genetic transformation.

\section{MATERIALS AND METHODS}

\section{Fungal isolate and culture media}

The LV 115 isolate of $C$. lindemuthianum belonging to race 65 was employed in the study. This clone was deriving from the culture collection of the Department of Biology, Universidade Federal de Lavras (Lavras, MG, Brazil). The isolate was maintained on $\mathrm{M}_{3}$ medium (Junqueira et al., 1984). To obtain high sporulation, the isolate was inoculated in sterilized green bean pods and was incubated at $22 \pm 2^{\circ} \mathrm{C}$ for $10-15$ days in the dark.

\section{Protoplast production of $C$. lindemuthianum}

The following factors were evaluated: osmotic stabilizer (type and concentration), mycelium age, enzyme concentration, and incubation time. Initially, the following seven stabilizers were prepared in $0.01 \mathrm{~mol} \mathrm{l}^{-1}$ phosphate buffer (pH 5.5) and tested: $\mathrm{MgSO}_{4}\left(0.6 \mathrm{~mol} \mathrm{l}^{-1}\right)$, Mannitol $\left(0.6 \mathrm{~mol} \mathrm{l}^{-1}\right)$, Sorbitol $\left(0.6 \mathrm{~mol} \mathrm{l}^{-1}\right), \mathrm{NaCl}\left(0.37 \mathrm{~mol} \mathrm{l}^{-1}\right), \mathrm{KCl}\left(0.37 \mathrm{~mol} \mathrm{l}^{-1}\right)$, Sucrose $\left(0.56 \mathrm{~mol} \mathrm{l}^{-1}\right)$, and $\mathrm{NH}_{4} \mathrm{Cl}\left(0.6 \mathrm{~mol} \mathrm{l}^{-1}\right)$. Later, the best osmotic stabilizers were evaluated at different concentrations. The enzyme concentration used for all experiments, except for the enzyme concentration experiment, was $10 \mathrm{mg} \mathrm{ml}^{-1}$. The mycelium ages tested were $48 \mathrm{~h}, 72 \mathrm{~h}, 96 \mathrm{~h}$, and $120 \mathrm{~h}$, using $\mathrm{NaCl} 0.6 \mathrm{~mol} \mathrm{l}^{-1}$ as the osmotic stabilizer. The enzyme concentrations tested were 10,20 , and $30 \mathrm{mg} \mathrm{ml}^{-1}$, using mycelium at $72 \mathrm{~h}$ and $\mathrm{NaCl} 0.6 \mathrm{~mol} \mathrm{l}^{-1}$ as the osmotic stabilizer.

A suspension of $10^{6}$ spores $\mathrm{ml}^{-1}$ were inoculated into $250 \mathrm{ml}$ Erlenmeyer flasks containing $30 \mathrm{ml} \mathrm{M}_{3} \mathrm{~S}$ medium $(\mathrm{Tu}$, 1985 ) and incubated at $22^{\circ} \mathrm{C}$ for $48-120 \mathrm{~h}$. The mycelium produced was washed with an osmotic stabilizer and the weight was determined (100 mg of hydrated mycelium). The enzyme solution was prepared using Lysing Enzymes from Trichoderma harzianum (Sigma) in $3 \mathrm{ml}$ of osmotic stabilizer and filtersterilized. The mycelium and enzyme solution were placed in a $25 \mathrm{ml}$ Erlenmeyer flask and kept under agitation (75 rpm) at room temperature for a period of 2-5 h. Three experimental measurements for each treatment were used. Protoplast release was determined by removing samples every hour and counting the protoplasts in a Neubauer chamber. The statistical significance of differences among mean values was assessed using an ANOVA and Tukey's student range test.

\section{Protoplast regeneration}

The digestion mixture was filtered through a slightly compacted cotton wool layer in a $5 \mathrm{ml}$ syringe. The protoplasts were collected and washed twice in osmotic stabilizer by centrifugation at $4000 \mathrm{~g}$ for $10 \mathrm{~min}$. The final pellet was suspended in $1 \mathrm{ml}$ of osmotic stabilizer and counted with a Neubauer chamber. The following osmotic stabilizers were tested in the regeneration medium (1\% Yeast extract, $0.05 \%$ casein acid hydrolysate, $0.05 \%$ casein enzymatic hydrolysate, 1.5\% agar): $0.6 \mathrm{~mol} \mathrm{l}^{-1} \mathrm{NH}_{4} \mathrm{Cl}, 0.37 \mathrm{~mol} \mathrm{l}^{-1} \mathrm{NaCl}, 0.6 \mathrm{~mol} \mathrm{l}^{-1}$ Mannitol , $0.6 \mathrm{~mol} \mathrm{l}^{-1}$ Sorbitol, and $0.56 \mathrm{~mol} \mathrm{l}^{-1}$ Sucrose. The osmotic stabilizer concentration was defined according Dias et al. (1997). The best osmotic stabilizers were evaluated at different concentrations $\left(0.6 \mathrm{~mol} \mathrm{l}^{-1}, 0.8 \mathrm{~mol} \mathrm{l}^{-1}, 1.0 \mathrm{~mol} \mathrm{l}^{-1}\right.$, and $\left.1.2 \mathrm{~mol} \mathrm{l}^{-1}\right)$. The regeneration medium with $0.5 \%$ sucrose was used as a control. Before plating, purified protoplasts were diluted in order to obtain a $10^{4}$ protoplasts $\mathrm{ml}^{-1}$ dilution. Subsequently, protoplasts from the dilutions were mixed with regeneration medium in $0.8 \%$ agar and poured into Petri dishes in order to have around 800 protoplasts per dish. These preparations were then incubated in a biochemical oxygen demand (BOD) incubator at $22^{\circ} \mathrm{C}$. In these experiments, $0.8 \%$ agar was used for plating the medium at low temperature to prevent protoplast damage.

Three replicates for each treatment were used and each replicate constituted of 3 Petri dishes. After 48 h, colonies were counted and the regeneration rate was calculated according to the following equation: Regeneration $(\%)=(\mathrm{A}-\mathrm{B}) / \mathrm{C} \times 100$, where $\mathrm{A}$ is the number of colonies developed in the medium A (treatment), B is the number of colonies developed in the control medium, and $\mathrm{C}$ is the total number of protoplasts per dish.

\section{RESULTSAND DISCUSSION}

The efficiency of the provided osmotic support to the protoplasts following the removal of the cell wall was evaluated for 6 different osmotic stabilizers. The best results were obtained with $0.6 \mathrm{~mol} \mathrm{l}^{-1} \mathrm{NH}_{4} \mathrm{Cl}$ and $0.37 \mathrm{~mol} \mathrm{l}^{-1} \mathrm{NaCl}$ salts, which produced an average of $9.6 \times 10^{5}$ and $8 \times 10^{5}$ protoplasts $\mathrm{ml}^{-1}$, respectively (Fig. 1). However, there was increased protoplast release at $4 \mathrm{~h}$ of incubation and the yields were $1.53 \times 10^{6}$ and $1.15 \times 10^{6}$ protoplast $\mathrm{ml}^{-1}$ for the respective stabilizers. Similar results were obtained in Penicillium expansum, Penicillium griseoroseum (Dias et al., 1997) and Aspergillus ochraceus (Almeida et al., 2008).

The use of $\mathrm{MgSO}_{4}$ as an osmotic stabilizer has been utilized more frequently for protoplast isolation in protocols for the genetic transformation of $C$. lindemuthianum (Rodriguez \& Yoder, 1987; Redman \& Rodriguez, 1994; Dufresne et al., 1998; Parisot et al., 2002). Sorbitol has been 
used in experiments with molecular approaches like PFGE, flow cytometry and PCR (O'Sullivan et al., 1998; Roca et al., 2003). However, the results observed with these stabilizers were unsatisfactory (Fig. 1). Therefore, it is possible that $\mathrm{MgSO}_{4}$ and sorbitol are not efficient when this enzymatic preparation (Lysing Enzymes) is used for this specie. Rodriguez \& Yoder (1987) obtained few protoplasts when Novozym 234 was used as litic enzyme in $\mathrm{MgSO}_{4}$ However, Fariña et al. (2004) obtained good results using Trichoderma harzianum enzymes in $\mathrm{MgSO}_{4}$ as osmotic stabilizer for Sclerotium rolfsii.

When evaluating different stabilizer concentrations relative to their salts $\left(\mathrm{NH}_{4} \mathrm{Cl}\right.$ and $\left.\mathrm{NaCl}\right)$, the best results were obtained with $1.2 \mathrm{~mol} \mathrm{l}^{-1} \mathrm{NH}_{4} \mathrm{Cl}$ and $0.6 \mathrm{~mol} \mathrm{l}^{-1} \mathrm{NaCl}$ (Fig. 2a-2b). These experiments showed that high concentrations of $\mathrm{NH}_{4} \mathrm{Cl}$ increased the number of protoplasts released (Fig. 2b). In contrast, for $\mathrm{NaCl}$ the best results were at the $0.6 \mathrm{~mol} \mathrm{l}^{-1}$ and $0.8 \mathrm{~mol} \mathrm{l}^{-1}$ concentrations (Fig. 2a). At a concentration of $0.6 \mathrm{~mol} \mathrm{l}^{-1}$ $\mathrm{NaCl}$, a higher number of protoplasts were released in a shorter incubation time ( $3 \mathrm{~h})$.

$\mathrm{NH}_{4} \mathrm{Cl}$ and $\mathrm{NaCl}$, although not previously described in protocols for protoplast production in C. lindemuthianum, have been used with other species of fungi. Good results have been found with $\mathrm{NaCl}$ in Colletotrichum capsici (Lalithakumari, 2000) and Colletotrichum graminicola (Epstein et al., 1998; Thon et al., 2000).
A greater release of protoplasts was observed from the young mycelium (48 h) (Fig. 2c) as previously reported for other fungi. However, due to the slow growth of $C$. lindemuthianum, it was difficult to obtain enough mycelia within $48 \mathrm{~h}$. For these experiments, it was necessary to inoculate a larger number of flasks to get enough mycelia. Satisfactory amounts of mycelium (0.3-0.35 g $\left.100 \mathrm{ml}^{-1}\right)$ had been collected after $72 \mathrm{~h}$ of growth.

According to Peberdy (1995), it is useful to have an understanding of the growth kinetics of the strain being used for protoplast isolation, but some of the most recalcitrant species for protoplast isolation are the slower growing fungi.

High enzyme concentrations (Lysing Enzymes, $30 \mathrm{mg}$ $\mathrm{ml}^{-1}$ ) resulted in the release of a larger number of protoplasts in a shorter digestion period (Fig. 2d). However, the number of protoplasts decreased with increasing digestion time. These findings were in agreement with those reported by Lalithakumari (2000) about the effects of lytic enzyme concentration on the number of protoplasts produced. The number of protoplasts increases with increasing concentrations of lytic enzymes, but high concentrations were sometimes harmful, resulting in the lysis of protoplasts soon after their appearance, thereby indicating toxic levels of lytic enzymes. Incubation time was another critical factor for protoplast production (Fig. 2d). In addition, enzyme concentration and digestion time may have a strong effect on the regeneration of protoplasts (Dias et al., 1996).

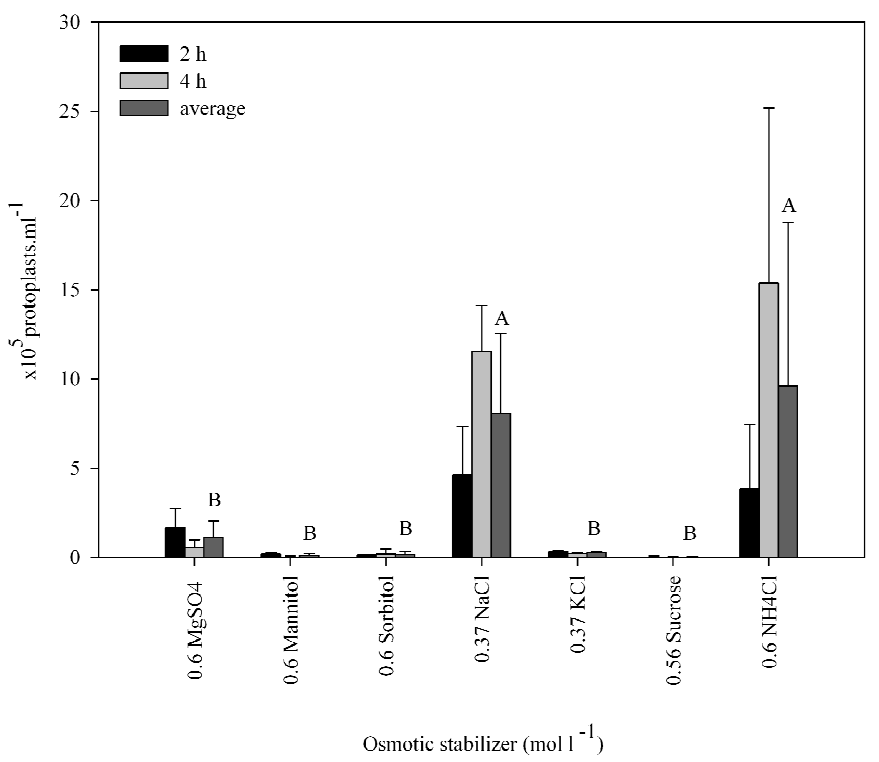

Figure 1 - Production of Colletotrichum lindemuthianum protoplasts in different osmotic stabilizers at equivalent molar concentrations. The digestion mixture included the following components: $100 \mathrm{mg}$ of mycelium (72h old) into $3 \mathrm{ml}$ osmotic stabilizer with $10 \mathrm{mg} \mathrm{ml}^{-1}$ enzyme. Incubation times were 2 and $4 \mathrm{~h}$. Means with the same letter are not significantly different according to a Tukey's test 5\%. Bar markers represent SD from mean values of three independent experiments. 
Notably, all of the factors evaluated including osmotic stabilizer, lytic enzyme, incubation time, and mycelial age significantly influenced protoplast isolation. Therefore, the optimal condition for protoplast preparation was incubation of young mycelia $(48 \mathrm{~h})$ in $\mathrm{NaCl} 0.6 \mathrm{~mol} \mathrm{l}^{-1}$ as the osmotic stabilizer with $30 \mathrm{mg} \mathrm{ml}^{-1}$ Lysing Enzymes for $3 \mathrm{~h}$.

Although protoplast formation in $C$. lindemuthianum has been reported before (Rodriguez \& Yoder, 1987; Redman \& Rodriguez, 1994; Dufresne et al., 1998; O’Sullivan et al., 1998; Dumas et al., 1999; Roca et al., 2003;), any existing protocol should be assessed for each strain under study. This concern has been supported by the significant differences found between protocols, protoplast yields, and regeneration rates.

It is already known that protoplast formation often constitutes the starting point for downstream genetic manipulation. However, protoplast technology is frequently problematic and often not reproducible, particularly for filamentous fungi. Therefore, purification protocols should emphasize the necessity to determine the key factors leading to successful results (Fariña et al., 2004).

Finally, good results for protoplast regeneration were obtained with sugars. Preliminarily, protoplast regeneration was tested using 5 osmotic stabilizers and the best results were obtained with sucrose at $0.56 \mathrm{~mol} \mathrm{l}^{-1}$ and mannitol at $0.6 \mathrm{~mol} \mathrm{l}^{-1}$ (Fig. 3a). These were evaluated at different concentrations and sucrose at $1.2 \mathrm{~mol} \mathrm{l}^{-1}$ or $1.0 \mathrm{~mol} \mathrm{l}^{-1}$ was the most suitable osmotic stabilizer for regeneration, with a rate of $16.35 \%$ or $14.54 \%$, respectively (Fig. 3b).

According to Dias et al. (1997), sugars are sometimes inefficient for protoplasts production but good stabilizers for regeneration. This may occur because sugars favor the osmotic stability for protoplast viability, but negatively affect the enzymatic digestion of the cell wall.
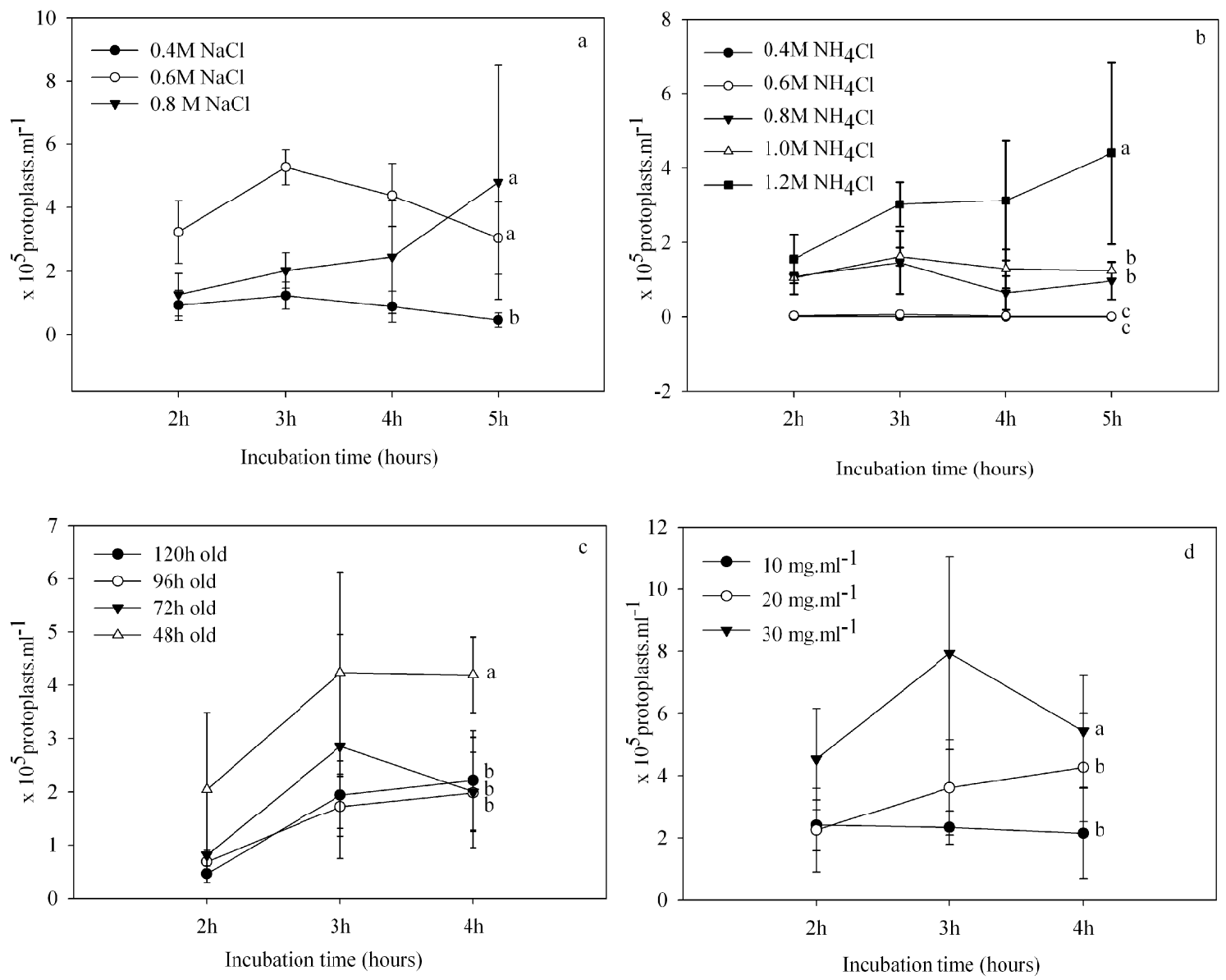

Figure 2 - Production of Colletotrichum lindemuthianum protoplasts under the following conditions: different molar concentrations of $\mathrm{NaCl}$ (a) and $\mathrm{NH}_{4} \mathrm{Cl}$ (b); mycelial age (c); enzyme concentration (Lysing enzymes from Trichoderma harzianum) (d). The digestion mixture included the following: $100 \mathrm{mg}$ of mycelium into $3 \mathrm{ml}$ of osmotic stabilizer. Means with the same letter are not significantly different according to a Tukey's test $5 \%$. 

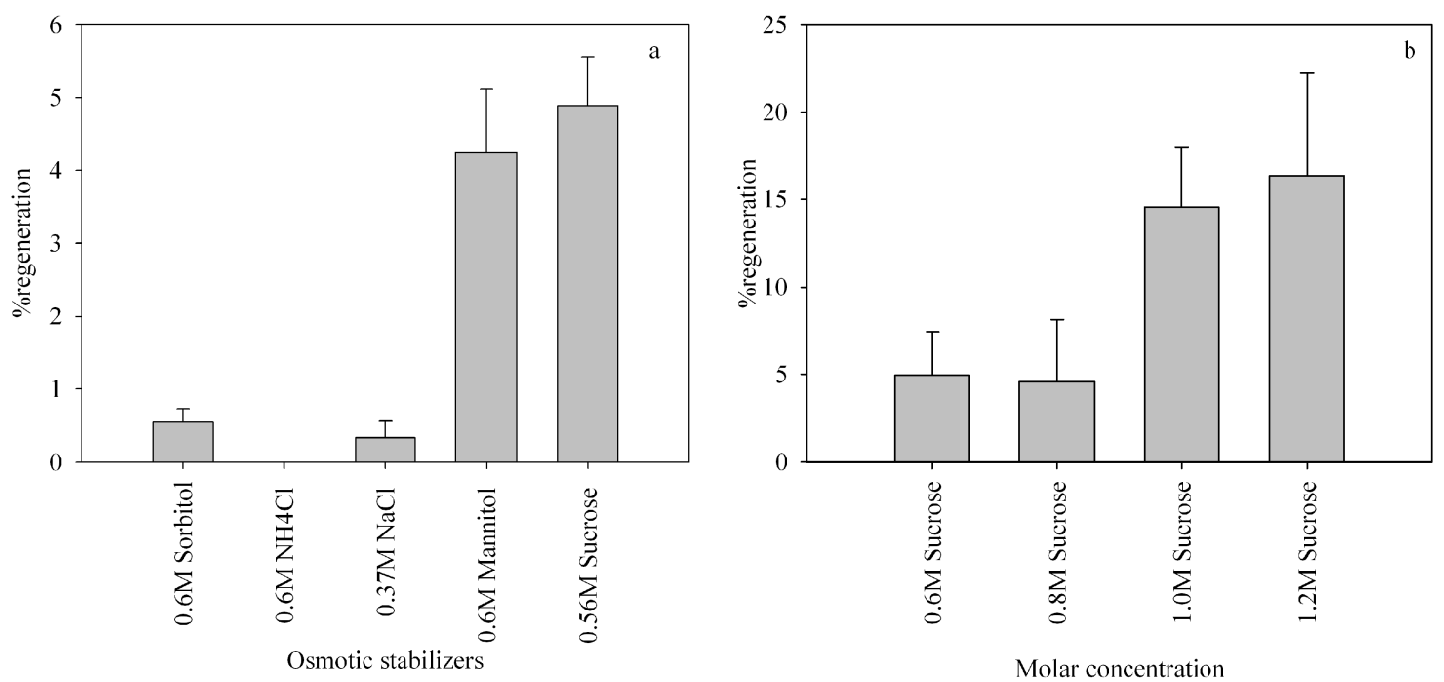

Figure 3 - Regeneration percentage of Colletotrichum lindemuthianum protoplasts. (a) After $72 \mathrm{~h}$ with different osmotic stabilizers (at equivalent molar concentrations); (b) After $48 \mathrm{~h}$ at different molar concentrations of sucrose.

\section{CONCLUSION}

In conclusion, this study demonstrated it is possible to optimize an efficient method for protoplast production and revert them into the typical mycelial morphology using the Colletotrichum lindemuthianum LV115 isolate. The usefulness of protoplast isolation is relevant for many different applications and has been principally used in procedures involving genetic transformation and electrophoretic karyotype. Thus, this work may improve our knowledge about this important plant pathogen.

\section{ACKNOWLEDGEMENTS}

This work was supported by fellowships to F. H. Ishikawa and Q. L Barcelos and financial support from CNPQ from Brazil.

\section{REFERENCE}

ALMEIDA, A.P.M.M.; DIAS, E.S.; PEREIRA, R.T.G.; TOLEDO, R.C.C.; PFENNING, L.H. Production of protoplasts from the filamentous fungus Aspergillus ochraceus. Ciência Rural, Santa Maria, v.38, p.14601462, 2008.

DIAS, E.S.; ARAUJO, E.F.; GUIMARAES, W.V.; COELHO, J.L.C.; SILVA, D.O. Production and regeneration of Penicillium expansum and Penicillium griseoroseum protoplasts. Revista de Microbiologia, São Paulo, v.28, p.116-120, 1997.
DIAS, E.S.; ARAÚJO, E.F.; GUIMARÃES, W.V.; MUCHOVEJ, R.M.C. Production and regeneration of protoplasts from the mycorrhizal fungus Suillus granulatus. World Journal of Microbiology \& Biotechnology, Netherlands, v.12, p.625-628, 1996.

DUFRESNE, M.; BAILEY, J.A.; DRON, M.; LANGIN, T. clk1, a serine/threonine protein kinase-encoding gene, is involved in pathogenicity of Colletotrichum lindemuthianum on common bean. Molecular PlantMicrobe Interactions, Saint Paul, v.11, p.99-108, 1998.

DUMAS, B.; CENTIS, S.; SARRAZIN, N.; ESQUERRETUGAYE, M.T. Use of green fluorescent protein to detect expression of an endopolygalacturonase gene of Colletotrichum lindemuthianum during bean infection. Applied and Environmental Microbiology, Washington, v.65, p.1769-1771, 1999.

EPSTEIN, L.; LUSNAK, K.; KAUR, S. Transformationmediated developmental mutants of Glomerella graminicola (Colletotrichum graminicola). Fungal Genetics and Biology, Amsterdam, v.23, p.189-203, 1998.

FARINA, J.I.; MOLINA, O.E.; FIGUEROA, L.I.C.

Formation and regeneration of protoplasts in Sclerotium rolfsii ATCC 201126. Journal of Applied Microbiology, Oxford, v.96, p.254-262, 2004. 
JUNQUEIRA, N.T.V.; CHAVES, G.M.; ZAMBOLIM, L.; ROMEIRO, R.S.; GASPAROTTO, L. Isolamento, cultivo e esporulação de Microcyclus ulei, agente etiológico do mal das folhas de seringueira. Revista Ceres, Viçosa, v.31, p.322-331, 1984.

\section{LALITHAKUMARI, D. Fungal protoplast: a} biotechnological tool. Enfield: Science, 2000.

O'SULLIVAN, D.; TOSI, P.; CREUSOT, F.; COOKE, M.; PHAN, T.H.; DRON, M.; LANGIN, T. Variation in genome organization of the plant pathogenic fungus Colletotrichum lindemuthianum. Current Genetics, Berlin, v.33, p.291-298, 1998.

PARISOT, D.; DUFRESNE, M.; VENEAULT, C.; LAUGE, R.; LANGIN, T. Clap1, a gene encoding a coppertransporting ATPase involved in the process of infection by the phytopathogenic fungus Colletotrichum lindemuthianum. Molecular Genetics and Genomics, Berlin, v.268, p.139-151, 2002.

PEBERDY, J.F. Fungal protoplasts. In: KÜCK, U. (Ed.). The mycota II genetics and biotechnology. Berlin: Springer-Verlag, 1995. p.49-60.

REDMAN, R.S.; RODRIGUEZ, R.J. Factors affecting the efficient transformation of Colletotrichum species.
Experimental Mycology, Amsterdam, v.18, p.230-246, 1994.

ROCA, M.G.; DAVIDE, L.C.; WHEALS, A.E. Template preparation for rapid PCR in Colletotrichum lindemuthianum. Brazilian Journal of Microbiology, São Paulo, v.34, p.8-12, 2003.

RODRIGUEZ, R.J.; YODER, O.C. Selectable genes for transformation of the fungal plant pathogen Glomerella cingulata f. sp. phaseoli (Colletotrichum

lindemuthianum). Gene, Amsterdam, v.54, p.73-81, 1987.

SOUZA, B. O. de; SOUZA, E. A. de; MENDES-COSTA, M. C. Determinação da variabilidade em isolados de Colletotrichum lindemuthianum por meio de marcadores morfológicos e culturais. Ciência e Agrotecnologia, Lavras, v.31, n. 4, p. 1000-1006, jul./ ago., 2007.

THON, M.R.; NUCKLES, E.M.; VAILLANCOURT, L.J. Restriction enzyme-mediated integration used to produce pathogenicity mutants of Colletotrichum graminicola. Molecular Plant-Microbe Interactions, Saint Paul, v.13, p.1356-1365, 2000.

TU, J.C. An improved Mathur's medium for growth, sporulation and germination of spores of Colletotrichum lindemuthianum. Microbios, Cambridge, v.44, p.87-93, 1985. 